\title{
Journalism, public imagination and cultural policy
}

\author{
Philip MacGregor*
}

\author{
Bournemouth University Media School, UK
}

\begin{abstract}
Although the phrase 'cultural policy' would rarely form on journalists' lips, the cultural results of journalism permeate national imaginations in the totality of their impressions, through processes of persuasion set-up within an apparent framework of choice. Problematic cultural effects are produced through the mechanisms of gigantic markets whose very randomness seduces observers into believing that they are protected from conspiracy and manipulation. The paper explores certain mystifications within the ethos of mass market journalism, whose professional techniques beguile both producers and public in the way they suppress criticism or sympathy, and eradicate all but populist positions. The paper contends that many journalists are fuelled by an ethos of puritanical anti-intellectualism. These themes are pursued by deconstructing some of the 'professional' codes in journalism and its didactic literature, in order to expose a mechanism for channelling public mentality that is condoned through the antiintellectualism of its techniques. The paper analyses media texts and processes of journalistic enculturation, engaging broadly with discourses inspired by the Frankfurt School and ideas of hegemony refined by Gramsci.
\end{abstract}

Keywords: journalism; markets; intellectual; cultural policy; implicit cultural policy

\section{Introduction}

The press and news media in Britain have received considerable attention over the years as shapers of public imagination and manipulators of opinion (Adorno 1991, Curran 2002). Indeed, with collapsing trust in politicians (Baines et al. 2004), the media perhaps meet even less opposition than formerly to their versions of consumer-led reality, while at the same time, especially with the internet, their original editorial output has massively expanded in quantity and reach. The general position of their enforcement of public compliance was an academic orthodoxy for some commentators 10-30 years ago, including political economists such as Chomsky (1988), but it has now become less influential and somewhat less pronounced in academic circles.

Typical of recent revisionist tendencies is Brian McNair (2006), though many others, like him, have drawn much attention to the presumed break-up of mass publics (demassification) and to the rivalry and consequent openness and diversity of the news media and online communication. Niche markets, the Internet, targeted media products and the digital empowerment of audiences are commonly said to fragment any totalising presence of media messages. This view contends that diversities and conflicting viewpoints represent pluralism at work and their range and counter-currents argue against sinister manipulations of the public into single viewpoints or attitudes. But such a benign perspective has to be contested.

*Email: pmacgreg@bournemouth.ac.uk

ISSN 1028-6632 print/ISSN 1477-2833 online

(C) 2009 Taylor \& Francis

DOI: $10.1080 / 10286630902746708$

http://www.informaworld.com
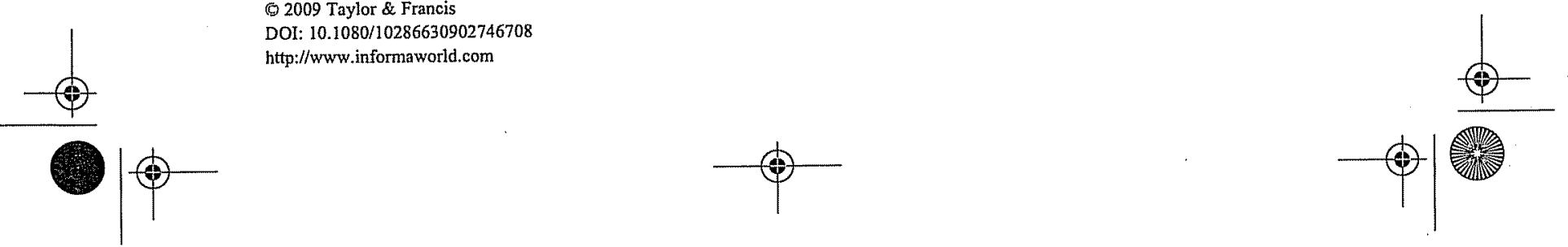
We could, rather, return to some propositions, such as those of Adorno (1991) and Gramsci (Simon 1982), which emphasise the repressive and coercive influence of media and detail their position as active agents of influence on decision-making by institutions of the state. Gramsci's formation of the idea of hegemony (1982) suggested that coalitions of 5 factions within ruling and powerful classes are continuously seeking advantage in relation to each other, which they do by engendering consent and expanding their influence beyond their own class through public persuasion. In this formulation, the state ruling classes, which in orthodox Marxism determine the ideas that structure the thinking of the rest of us, separate into factions within civil society and compete for real influence on social and policy

10 direction by reaching into the public imagination. Among the core agencies are lawyers, the church, official politicians and the armed forces. These are surrounded by other less coercive groupings, such as schools, universities and trades unions. While today we would add corporations as distinct producers of ideological content, it is the media especially that have expanded beyond any scope Gramsci could have foreseen. Even Adomo, with all his prescience and totalising tendencies of thought, barely envisaged the extent of the media in modern cultural production and exchange. If, as McGuigan suggests (1996, p. 1), 'cultural policy ... is about the clash of ideas, institutional struggles and power relations in the circulation of symbolic meanings', then the media can indeed be seen to be powerful agents of cultural policy, playing a hegemonic role in their direct influence on almost all public symbolic processes.

Following this, the next point to note is that they do not adopt neutral positions. On the contrary, as we shall see, they construct formidable cultural and political attitudes, which not only administer comfort (Bernstein 1991), but also promote mythologies that are as strong as, or stronger than, any that the core state apparatuses can foster or negate. By mythologies, I mean to imply not just distortions and half truths, but also the reproduction of narratives or fragments of narratives - often pernicious constructions of fake history or forms of nationalism - which promote beliefs and are maintained in circulation within the press.

However, these questionable narratives are born in a surprising milieu. They arise para30 doxically within a journalistic culture of professional attitudes that overtly banishes falsity, pretension and obscurity. Indeed, the press in more than one country often leads the way in setting up vehement attacks on any institutional language that serves what it deems to be non-transparent motives. This is mainly perpetuated through the principles impressed on every new media recruit - of brevity, objectivity, balance and neutrality. These principles 35 are fairly ubiquitous and remarkably durable in press rationales (Deuze 2005), but in their application they are consistently betrayed.

How does it arise that media language, in supposedly avoiding ambiguity, is transformed into extremes of value-laden phrases and words. The results permeate the UK civil and political spheres, helping to inculcate standardised, uniform positions on all kinds of 40 political and cultural affairs with little argument, and based on a narrow range of unexamined premises. The paradox results in critics of news media and public communication berating them for bias, while their authors defend their products as 'truth to reality', legitimated by stringent codes of practice. I would suggest that purity of expression is idealised by the media, only to be re-appropriated by them as a vehicle of falsification.

The ideal of clarity seems to have been re-possessed by ideology, a mutation that has

45. The ideal of clarity seems to journalism to the very political language that Orwell (1970) ridiculed - political language that 'makes murder reasonable and gives solidity to the wind'. It is achieved in the press of many countries, not only by its version of professed clarity but also by techniques of abbreviation. 


\section{Framing and media consensus}

Two examples of the tendencies outlined above will show how British journalists conduct critical distortions through a mythologising process of 'clarity': first, through the way in which the ideas for racial harmony, proposed by a leading religious figure, were represented in early 2008; and secondly the framing of immigration issues over 2007/2008. Both cases highlight the abuse of so-called 'simple language'.

The Archbishop of Canterbury, Dr Rowan Williams, is the leading prelate of Anglicanism, which is the constitutionally endorsed version of Christianity in Britain. Williams' case may help to demonstrate how consensual forces shaped language choices and meanings in media interpretations of a speech he gave at the Royal Courts of Justice in London on 7 February 2008, entitled 'Civil and Religious Law in Britain, a Religious Perspective' (Williams 2008). The media reports had an important effect on the public perceptions of the possible ways to live in Britain with Islamic co-citizens. It can be said at the start that we were presented with a piece of cultural thinking that in some respects, in Arnold's phrase, 'turns a stream of fresh and free thoughts upon our stock notions and habits' (Williams 1958 , p. 124). Archbishop Williams suggested that in multicultural Britain legal systems might to some extent co-exist in a multilayered form, so as to permit diversity and inclusion, where that was possible, without compromising principles and practices of existing UK law.

$\mathrm{He}$ was not advocating moral or legal relativism because, first, he acknowledged that there were many un-tradeable elements in English jurisprudence; and secondly, because he was seeking to reach out to those holding communal loyalties, such as Muslims, and bring them into a direct relation to the state, while allowing legal flexibility on significant but subordinate identity definers for citizens of different histories and beliefs. On one level his was a plea for inclusivity.

However, a speech that intended only carefully defined ambiguities was actually represented in media in such a way as to allow its substance to be ignored or radically distorted. A headline in The Times newspaper described Williams' writing as 'obscure' and the ensuing article then dubbed it 'complex' (9 February 2008). The point, rather, is that his writing expressed complex thoughts, whose difficulty lay in relation to precision of expression and to balancing priorities, to moving between general and particular and to evolving terms that did not carry prejudicial connotations.

What form did this media distortion take? First, only a tiny number of press articles made even a token attempt to report more than two or three sentences of his speech of 6220 words. Even those reports were often truncated or reduced to a two-word phrase. But secondly, much of the press in fact ignored the actual speech altogether and picked instead a remark he made in a BBC Radio 4 interview that incorporation of Sharia law into Britain 'seems unavoidable'.

Instead of balance or context, there was a journalistic pack instinct to 'report' this one statement that was not in his speech at all: that Sharia law was going to be introduced in Britain and that this was 'unavoidable'. But Williams' speech only suggested that some analogy with a market system of law was 'unavoidable' [my italics]. It was in a BBC Radio 4 interview the following day (World at One 7 February 2008) that Williams did say that 'it seems unavoidable' [that Sharia is applied in certain circumstances].

However, he immediately went on to qualify his statement by observing that 'indeed as a matter of fact certain provisions of Sharia are already recognised in our society and under our law'. In other words, he pointed out that it was de facto in place already. It should also be noted that it was the interviewer who proposed the word 'unavoidable' and it was therefore to be expected that Williams might redeploy it in his answer.
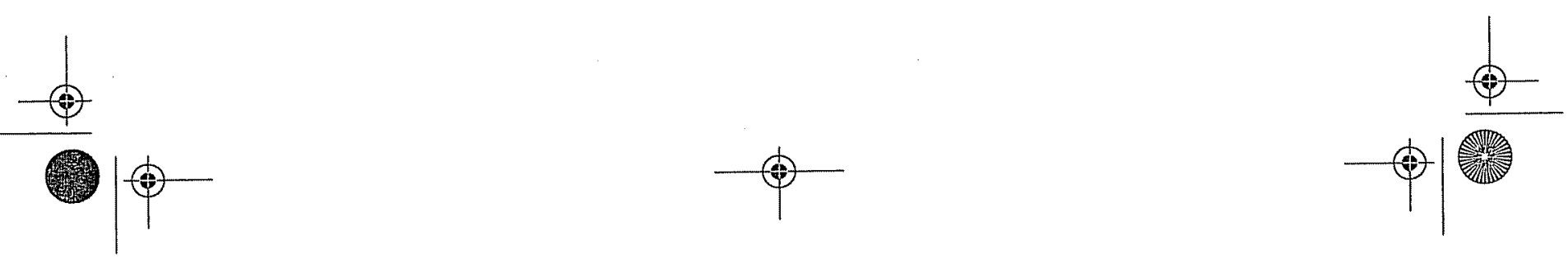
'Unavoidable' was the word that the press and the $\mathrm{BBC}$ focused upon remorselessly and almost exclusively. Even the rest of that sentence was never reproduced, which stated that aspects of Sharia were already in operation in England. Williams' next sentence, 'So it is not as if we are bringing in an alien or rival system', was not used in any of the media. Nor was the statement that 'we already have in this country a number of situations in which the internal law of religious communities is recognised by the law of the land'. These provisos are essential to understanding what he meant to convey.

This accent on one word is simplification to absurdity. Many positive things could and should instead have been said about his position. At the very least it is a standard argu10 ment for pluralistic thinking, namely that there may be, as Williams put it, a 'diversity of moral reasoning' in a plural society. If a rationally based response to social problems is required in a liberal democracy, the free and accurate expression of views is an essential part of maturing a reaction, of finding, in the terms of John Stuart Mill (1859), the best arguments to emerge by allowing them to compete with one another in public on equal terms.

Only one writer made much attempt to précis the totality of Williams' speech, and she, Deborah Orr in The Independent, was almost a lone Press voice in defending the substance of the article (Orr 2008, 9 February). None of the press, incidentally, rose to claim for Dr Williams the right of free speech; and whereas his stated aim was to promote social cohesion, it was mostly relayed as intending ghettoisation.

Important qualifications that formed the fabric of his speech were mostly omitted or perverted, such as:

- a local monopoly of law cannot be allowed;

- Sharia law is evolutionary and culturally various;

- even Sharia states develop ideas of civic good apart from their legal precepts;

- his aim was the destruction of 'crude oppositions and mythologies';

- Williams suggested the word 'delegated' power to community courts, whereas the press dwelt on a presumption that he had said 'parallel'; and

- he expressed abhorrence for some state codifications of Sharia, based on both its nonrecognition of equality between sexes and its mediaeval punishments.

In the hands and minds of most of the press and the BBC, the Archbishop's speech grew a meaning of its own with its own invented certainty, which was transferred in an inflammatory way to a mass audience. In recognition of this, Williams' press office issued a statement during the furore, emphasising that the 'Archbishop made no proposals for Sharia in either the lecture or the interview, and certainly did not call for its introduction as some kind of parallel jurisdiction to the civil law' (Archbishop of Canterbury 2008).

This brief account demonstrates the extent to which Williams' speech was monolithically 40 misrepresented across much of the UK media. Within the mainstream media outlets there was no pluralism of views and interpretations, nor was this deficiency significantly rebalanced by interactive or re-interpretative citizen journalists, though one or two blogs with wider sympathies took issue with the reporting accuracy and public condemnation (Cranmer 2008, International Union for Muslim Scholars 2008, Media Workers Against the War 45 2008). When a considered contribution from a leading public figure on an issue of major political and cultural importance can be so consistently misrepresented in the ways described, it casts serious doubts on some of the affirmative theories of media pluralism that are currently in circulation. These tend to be linked to the Internet and globalisation (Katz 2001 cited in Allan 2002, p. 134, McNair 2006).
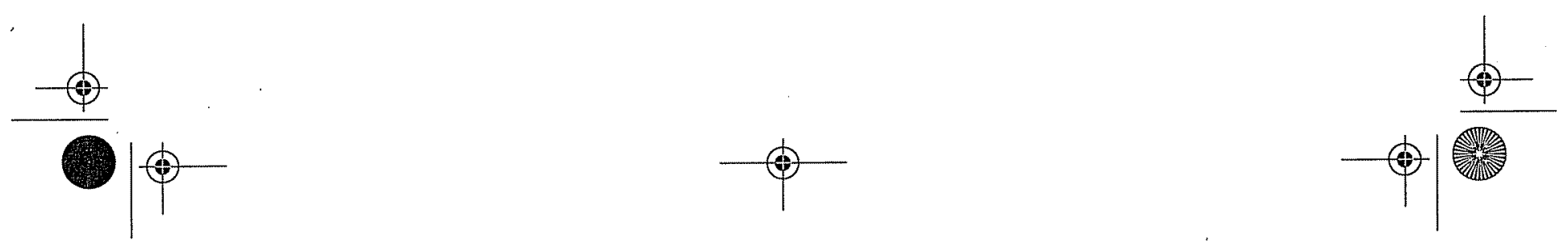


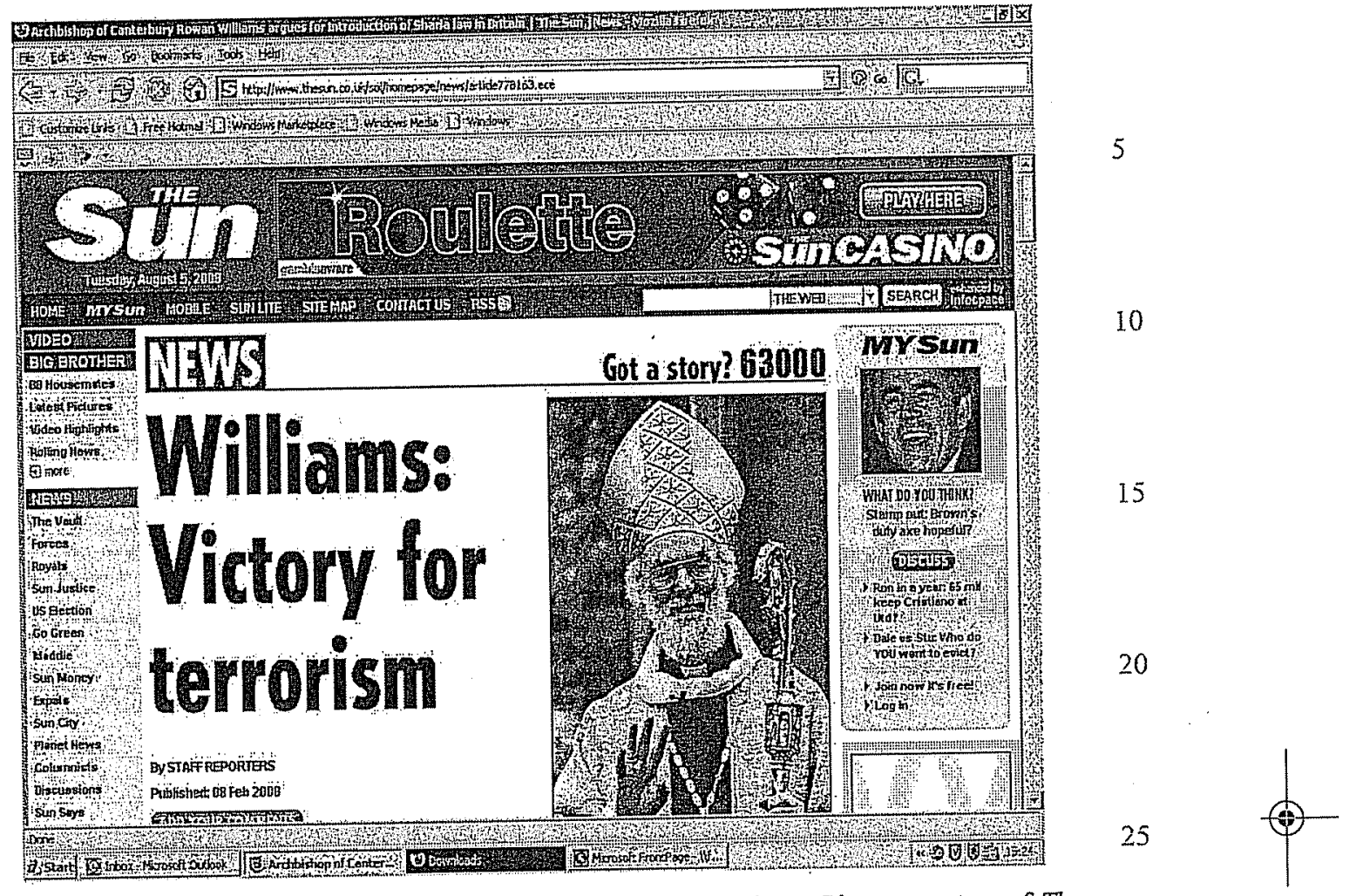

Figure 1. How the British newspaper The Sun portrayed the Sharia issue. Picture courtesy of The Times/NI Syndication.

The second example is the more general one of immigration into Britain, although a similar survey in other European countries might produce a comparable result in spite of different national regulations. In this case, a collection of headlines were taken from June 2007 to April 2008 on an electronic search across a range of national UK press from the database, NewsUK. The items, using the search terms 'immigrant' and 'migrant' in the headlines, were taken from the following sources: The Times, Daily Mirror, Daily Mail, Daily Express, The Independent, Financial Times, The Sun, Sunday Times, Observer, News of the World and Daily Telegraph. The articles displayed consistently intolerant tendencies of thought, developing what Teun Van Dijk $(1988$, p. 213) has called 'construction of the ethnic consensus that underlies the racist ideologies and practices of our society'. The consensus fortifies a climate in which institutions and Government can and do counter even their own inclinations to tolerance (of the same kind that still banishes capital punishment) in the interest of potential votes and popularity.

The debate was fuelled between 2006 and 2008 both by an influx to the UK of Europeans newly seeking relocation as new EU members and by some counting errors by the Government department responsible for immigration issues, the Home Office. Of the headlines and articles surveyed, at least $80 \%$ could be taken as negative to the well-being or acceptance of newly arrived citizens, with the remaining $20 \%$ neutral or positive.

Headlines studied declared a series of themes, such as: immigrants take the UK jobs, queue jump for housing, increase crime (especially murder), ruin the countryside, waste

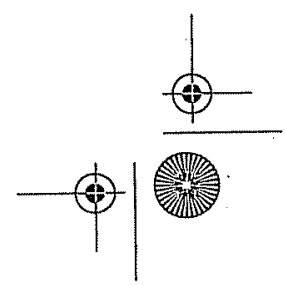


public money on integration schemes that fail, increase loads on public services such as health and education, take benefits and burden welfare, menace 'our' roads with bad driving, threaten to outnumber native English, outperform white pupils in schools, depress wages for native workers and add nothing to the standard of living. The reports conveyed a Malthusian sense that Britain would be tipped into a population crisis with apocalyptic estimates of both proportions of migrants, absolute numbers and dilution of ethnic UK stock by over-reproduction of foreign nationals. Foreigners even knocked 'our tramps' off the streets (News of the World, 6 January 2008, p. 22). When immigrants did leave, they were depicted as ungratefully 'turning their backs' on the country (Daily Mail, 25 March 2008, p. 6). These negative themes, portraying immigrant co-citizens as deviant and parasitical, closely mirrored those found by Van Dijk (1988, p. 209).

Rhetorical devices of comparison typified estimates, with an inverted appeal to patriotic heritage such as 'more than the numbers in West Yorkshire'. Newcomers in numbers 'equivalent to ten cities the size of Birmingham and seventy percent of the increase will be due to immigration' (Sunday Times, 4 November 2007, p. 19). There was an interesting flurry of conflated moral panics after a European report suggested that climate change would lead immigrants to flood in from globally warming parts of the world. Borders were depicted, again with liquid imagery, as being 'porous' (Sunday Times, 15 July 2007, p. 4) as though in a civilised well-run country they should be otherwise.

What was never reported was the suffering and exploitation of foreign workers, although it was alluded to in the institutional reports quoted, such as the report on the 'Economic Impact of Immigration' by the House of Lords Select Committee on Economic Affairs

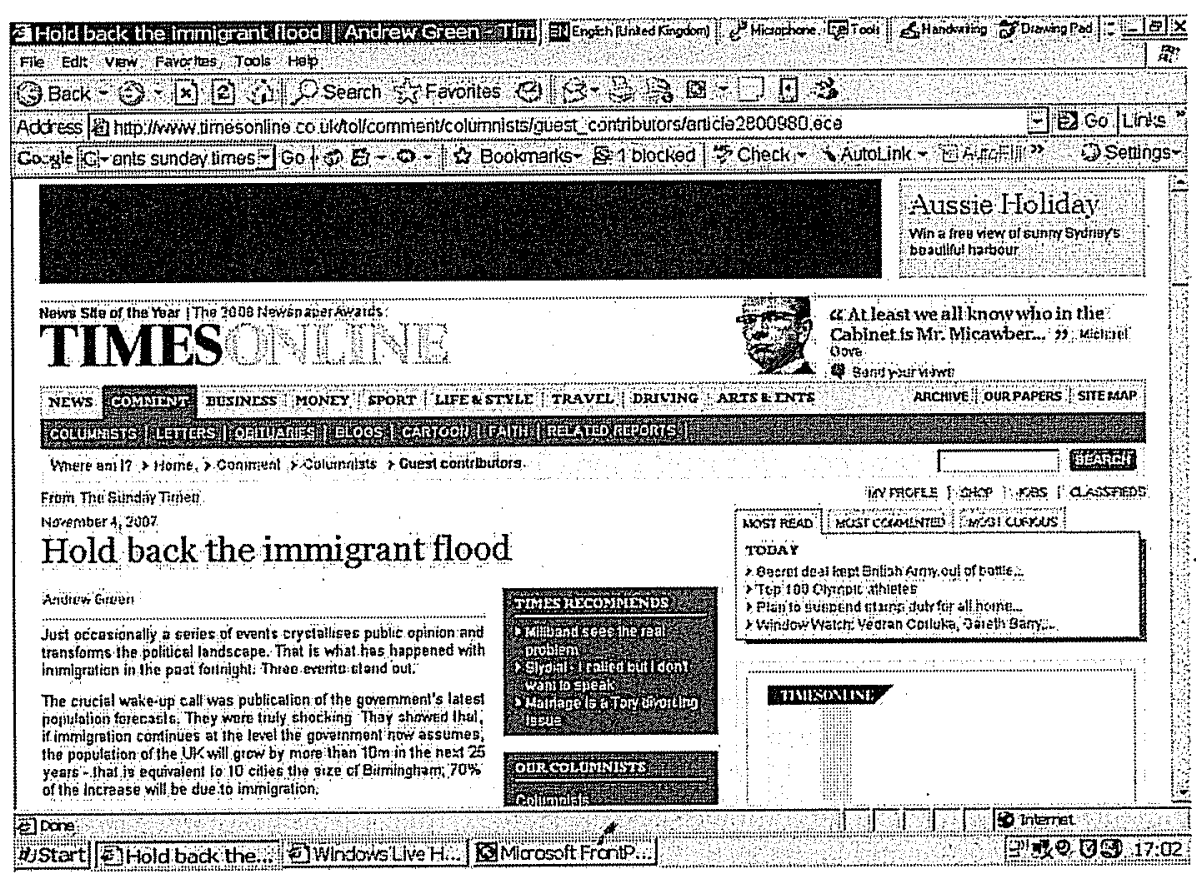

Figure 2. Andrew Green of the Sunday Times uses multiples of Birmingham's population to suggest uncontrollable growth due to immigration (November 2007). Picture courtesy of The Times/NI Syndication.

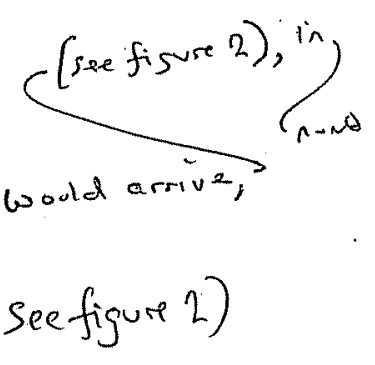


(2008). Indeed, it was hard to discover in any of the mainstream press accounts of the conditions experienced by so many newcomers - the squalor, the victimisation and the economic dependence in some settings, especially of asylum seekers, that often denied basic human rights. ${ }^{2}$

The language was rarely neutral. Reports had frequent recourse to clichéd, inaccurate metaphor. The most common terms were inimical to breathing life, 'flood' being especially prevalent in a range of headlines. According to the Sunday Times (1 September 2007, p. 19), 'the immigrant trickle ... became a flood' and the greatest legacy of the Labour Government would be a surge in numbers of immigrants that would result in the biggest change in ethnic British character in 900 years. This use of 'flood', 'tide', 'trickle' and 'wave' was consistent with press imagery over a period of 30 years (Cohen 2002), an endless drip of mythologies on the public imagination, spread across all written media. As Cohen has also pointed out, ' $t$ ] he naturalisation of certain metaphors can blur the boundaries between the literal and the non literal' (p. $x x$ ).

Few voices of criticism appeared in this selection of articles studied, an exception being the leader of the Polish community in Britain, Wiktor Moszczynski, who was the Daily Telegraph's solitary voice of critique of both the methodology and content of the report of the House of Lords Select Committee, mentioned above.

Most headlines made sharp, negative points, often without balance. For example, that foreigners committed most murders in Britain was picked as the angle for a Times headline (1 December 2007, p. 3), although the text showed that victims were also foreign. A less loaded headline might have been 'Most UK murder victims are foreign'. The substance of the newspaper article was also more diffuse than the headline implied, concentrating on the extra costs of solving culturally alien crime.

It was striking that the popular and the highbrow papers in the UK were not easily separable, in their headline content or nuance. They assumed the same prejudices and took the same headline points. There was, for example, wide agreement by the newspapers on the negative news angle to take on the Select Committee report, which, they said, claimed that the economic benefit of immigration to Britain was zero. The report actually concluded that immigration had a small, positive economic impact on the UK rich and a small, negative impact on its lowest paid workers (para 217, p. 59). The headline on the Select Committee report could thus more positively and with equal faimess have been constructed, 'Proven: Immigrants do Britain no economic harm'.

Given the cut-throat competitive nature of the UK press, and the commercial advantage that might seem to accrue from diversity of opinion, the convergence on negativity in all these cases is surprising. Admittedly, The Guardian newspaper is not part of the sample, but its differing sympathies would scarcely offset the congruence of viewpoints that is apparent here across much of the national press, and especially The Times, News of the World, Daily Express and Daily Mail.

\section{The enculturation of the journalist}

In the cases of both the Williams controversy and the immigration issues, the important point is not only that these news distortions are taking place but also that destructive mythologies are being created in journalism in contradiction to one of its most powerful beliefs about its own practices. Its chief articles of faith include the pursuit of simplicity, accuracy and clarity - essentially, to de-mythologise. The paradox is that these astonishing racist biases and myths emerge from the media in spite of its own self-justifying claims of clarity, balance and neutrality. 
Indeed, under the guise of 'jargon-busting', a prime element of the rationale of journalism is that much of its output is in some way superior to that of the civic communicators whose output it handles. Press releases, agendas, committee minutes, government statistics, letters and Emails from public servants are all put through one mill, one journalistic process, 5 whose byword is 'simplify'. As Orwell noted (1970, p. 165), 'so far as writing goes, all one can attempt is a process of simplification'. Such simple language is intended to be close to that of natural speech. Syntax is reduced to essentials. The press training manuals advocate the sentence containing 'a single idea'. Under this principle, the apparent aim is to destroy bombast and to reduce complexity to a core meaning, without distortion, neutrally and

10. fairly. For example, in its News Style Guide, the BBC advises its journalists that 'the key to good writing is simple thoughts simply expressed', and that they should 'use short sentences and short words' (Allen 2008). In his admired text on journalism, Leslie Sellers devoted full chapters to simplicity and accuracy, arguing that 'nothing that can't be absorbed at one go should appear in a newspaper' (Sellers 1985, p. 45).

15 How can this paradox be explained? How does it arise that while the press has evolved a reasoned legitimation of its own activities that idealises accurate discourse in plain language, its actual product so often tends towards mythology and the sacrifice of its own principles? One possibly overlooked explanation is the process of enculturation of the journalist. The regime of on-the-job news training is, in this author's view, illiberal and repres-

20 sive. Practices are learned through the system of 'news values' (Tunstall 1971, Hall 1978). A common theme is the certainty with which senior staff hold their values and the severe measures taken to ensure compliance with these values. In the name of neutrality, factual items are handled in such a way as to forbid deduction or the drawing of conclusions by the journalist. Logical thought is thereby condemned as comment and 'editorialising'.

However, news values do not come 'naturally'. For example, in April 2008, the author, whose professional role is a journalism teacher, was phoned by a trainee journalist in Sky News in the UK. The student had interviewed a former Olympic champion athlete, who appeared to have made highly critical comments about the International Olympic Committee. Sky editors were asking him to angle his story in such a way as to suggest that the
athlete thought the Olympic committee should never have awarded the games to China.

The student was deeply concerned that the athlete's words were being taken out of context and that the sense of what had been said was being pushed too far. Nevertheless, Sky News used the story as it preferred as its lead item in the online section, deciding that the interviews warranted the statement that the Olympic committee had made a mistake.

35 The case is an example, not of bad journalism, but of the 'unnatural' feel that news values have to intelligent people who are new to editorial procedures.

This training is ruthless and refuses criticism. ${ }^{2}$ The system is underpinned by overt threats to employment security. Stories of the brutality in news rooms are folklore. One former journalist described how his writing as a trainee would be torn up in public in front of him and how his creativity was 'pummelled' out of him. His sense of disorientation was enormous, thus empowering his trainers to indoctrinate effectively. He went on to work in newspapers and news agencies, having been, as he put it, 'battered into submission'. Another former journalist described what happens as 'a softening up process'. He is still shocked by the sense of 'righteousness' of editorial figures and the astonishingly uncritical certainty of their 'important mission to deliver the truth'.

These common psychological techniques attest to a regime of news production whose unstated rules of procedure enforce compliance. The 'free' media operate under the direct influence of those personalities who control newsrooms. The environment perpetuates allencompassing interpretative systems that are often the antithesis of liberal values of doubt, 
uncertainty and sensitivity. The enculturation works through devices, such as ridicule and embarrassment, and is ubiquitously applied so as to fortify only the media's version of consensual norms. Journalists today in Britain are likely to share common assumptions about truth and untruth, reason and unreason, and very often, about the imagined naivety of protest, or innovation.

We can therefore suggest with some evidence that the journalists' biases, or those inculcated in compulsory routines of editorial offices, are probably affecting vast sections of the popular imagination through impressions given by their outputs (Curran 2002, p. 77, McLaren and Johnson 2004, p. 189). As Colin Sparks put it, 'the contents of the media are a powerful contributor to popular knowledge and opinion' $(2003, p .1)$. The Archbishop of Canterbury found himself confronted by a collective institutional view of the place of Islam in the modern state of Britain. He was unswervingly misrepresented to appear to flout European traditions of rights and equalities on the one hand and to maintain a subordinate and even semi-outcast status to probably innocuous practices of co-citizens on the other. Even more strangely, the archbishop's liberal aspirations of accommodation and toleration with which Britain has been linked since the seventeenth century (Kamen 1967) were distorted to make it appear that he was handing 'victory to terror' (The Sun, 8 February 2008, p. 8). This is the formation of a cultural policy, a 'nationalistic' consensus, one that is based on the reproduction of social populist norms defined initially by journalists and developed by the people they invite to talk.

\section{Cultural policy in the making}

Such methods amount to a cultural policy of stupendous scope, implicit or otherwise, which in the UK is projected towards an audience of millions. If we include the BBC, which was a prime actor in the Williams affair, this audience might well amount to $30 \%$ of the adult voting population. Political economist critics of journalism used to distinguish the popular and the highbrow press and broadcasters, assuming a degree of difference in the information content and reason available via the quality media (Curran and Seaton 1988) but this is hardly borne out in this example.

Immigration provides an equally monolithic picture. I have discussed the themes in the current contemporary media, especially the press, and shown the scale of the representational myths and distortions. It is no mere accident but can be traced back through 30 years of the UK journalistic output. Van Dijk $(1988$, p. 212) reflects that 'a large part of the public consensus can only have come through mass mediated communication and information', and that the media 'not only play an active role in the production of negative attitudes but in our present society this role is vital'. He goes on to suggest that the media 'autonomously reinterpret and reconstruct and contribute to the racist ideology that underpins our society" (1988, p. 213).

We might add here that this racist ideology is a cultural policy in the wide sense of the word, as in Raymond Williams' 'signifying system' and encapsulated recently by Oliver Bennett, who suggests that it includes 'all those attempts that have taken place over time to assert or prohibit cultural values or practices' (Bennett 2006, p. 124). In an earlier account, Bennett also characterises cultural policy as the "the totality of actions taken within these [arts and media] sectors, together with the measures adopted by both central and local government to support or regulate them' (Bennett 1995, p. 111). The 'totality of actions' is shown here to follow a surprisingly narrow, focused agenda and to potentially inculcate the public with attitudes that can be absorbed at any moment across a range of media platforms. This is a cultural policy that is almost impossible to ignore. It works from a basis of
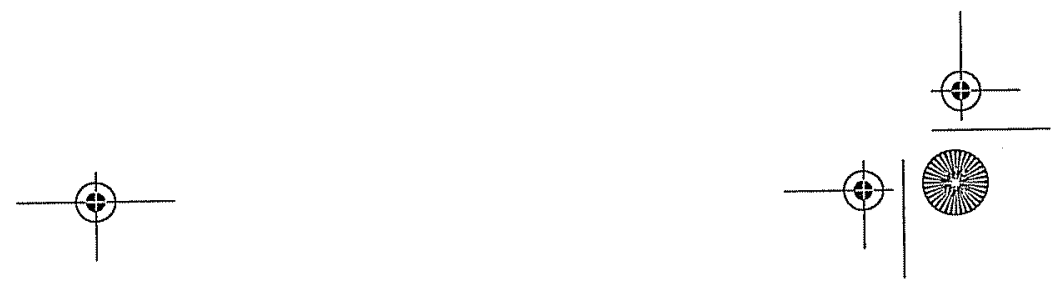
careful framing and distortion, often flying in the face of those precepts of balance that give journalism its public defensive credibility. Gaye Tuchman (1978) came close to defining the instrumental quality of the professional attributes of journalism, but even her characterisations of its 'defensive rituals', avoids the presumption that they are applied as cynically, or at least deviantly, as they sometimes are.

Before leaving this topic, we should dwell a little longer on the idea of a tacit cultural policy, which frames the current argument. For a cultural policy to be a policy, it might be argued that there has to be explicit intentionality, and that it has to be conscious before the moment of public dispersal. This is the definition Bennett appears to espouse when he suggests that cultural policy is 'the deliberate intention to work on the culture of a people' $(2009$, p. 157). It might therefore seem that labelling the media content as covert policy suggests only partial fulfilment of those definitional components, since 'deliberate' is apparently missing from the so-called policy. Before addressing this point, it can first be said that the practical examples given so far do depict media working on the 'culture of a 15 people'. Also, since the media never use the phrase 'cultural policy' to apply to their work, any policy is by definition thereby implicit, covert and tacit. One should exclude the increasingly rare claims of corporate media owners that they do or wish to shape policy. For the most part, as the doctrine of neutrality implies, few such policy claims are made, publicly or privately, within the marketised news media.

However, it is not really necessary to argue that a policy has to be deliberate for it to be a policy in effect. Indeed, in Gramsci's articulation of power relations, or in Nye's (2005) nuanced version of 'soft power', quite the reverse is true. Drift is technically in many contexts a policy. It is also often so that activity with conscious intention covered by some other term, such as 'brand power', 'right to know', or any activity linked to belief and identity like faith practices, can amount to a policy if collectively understood and applied. Suffice to say here that intentionality can be disguised, or diffused into other objectives, or even absent, for there still to be a cultural policy or application of power, when viewed from another discourse standpoint.

\section{Journalism and intellectuals}

One further factor to be considered in the way that journalists frame the news is the complicated relationship that journalists - and indeed the British public - have often had with intellectuals. Journalists will not self-describe as intellectual. It is doubtful if there is any

35 case of a modern British journalist calling themselves one, with the possible exception of Melvyn Bragg. Cynicism and scepticism they will admit to, along with scrutiny, but the word intellectual has always aroused hostility, and not only because it is associated with pretension. The aversion stems from a deep dislike of abstraction and particularly of systems and systemic thought. Academic critics note personalisation as a key feature of the press (Galtung and Ruge 1965). Some qualities associated with the idea of the intellectual, namely those of moral independence (Said 1994, Bennett 2006) and the ability to draw consequences that can be acted upon, meet only suspicion, not just of the substance of the argument or matter, but also of the type of individual who might be advocating it. Antiintellectualism was noted by Orwell as early as 1944, when he saw journalists as working generally to promote distrust of thinkers and 'despise the highbrow' (1970, p. 53).

Any abstract noun tends to engender a negative reflex in the journalist. The exceptions are terms of abuse. This tendency towards the concrete is part of the job training and advocated specifically by writers of journalism guidance books (Sellers 1985, Harris and Spark 1995). General ideas like 'democracy', 'social inclusion' or 'pacifism' in the abstract - though not
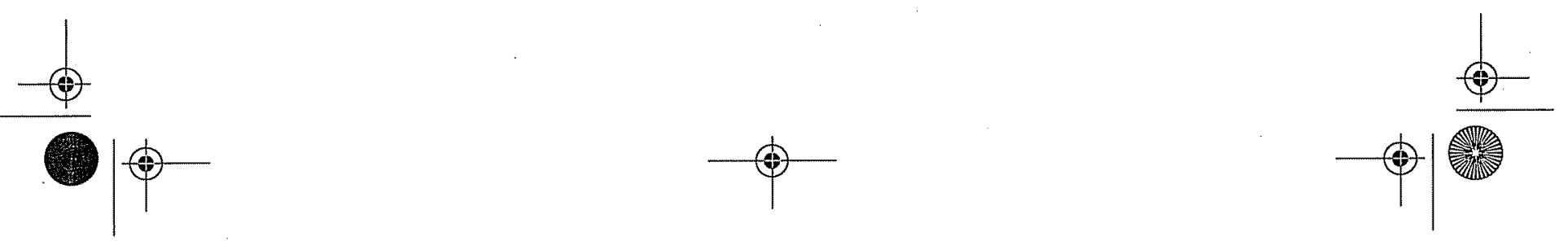
of course patriotism - may be portrayed as cant in disguise, and the motives of their users are assumed to be manipulative or naïve. Distrust of these abstractions may be justifiable since politicians are so likely to use them rhetorically. The issue is difficult. But Furedi (2004, p. 74) is probably right when he suggests that a "public that is permanently spoon fed platitudes and sound bites is likely to become estranged from the world of political debate".

In terms of anything 'highbrow' - a derogatory term first noted as such by Leavis (1930) - the press always advances caution and is quick to ridicule. So wide is the sweep of distrust of 'elite' culture, or heightened sensibility that their shadow barely falls on mainstream news media. While cultural elites in Britain themselves became anti-elitist in the $1970 \mathrm{~s}$, preferring to advocate popular culture, the press and television by and large already needed no conversion. In parenthesis, one might note that this tendency has complex historical roots. In the 1920s and 1930 s in Britain, the intellectual was an elitist of a much more viciously anti-democratic type than is often relayed (Carey 1992). People were objectified as masses to whom were attributed animal characteristics, while intellectuals and writers such as D.H. Lawrence were quite ready to contemplate, even desire, their active extermination (Carey 1992, p. 11). Therefore, to attribute anti-intellectual developments in journalism only to 'populist' market forces driving down standards - 'levelling down' as Gissing put it (Young 1961) - does some disservice to the journalists who in the mid-twentieth century wanted to distance themselves from fascistic ideas.

Nevertheless, today the doctrine of simplicity, with its engaging ideal of demotic language, goes hand in hand with a puritanically anti-intellectual trend in the UK journalism. There is a battle against euphemism, high-minded in its intent, but erroneous in assuming there are always value free alternatives. Anti-intellectualism becomes a fellow-traveller within this linguistic purging sentiment, since the aversion to certain word choices transforms itself into a mission to repress 'higher' or abstract expression. The value-neutral 'craft' training in journalism is actually infused with anti-intellectualism as such, which reinforces a revulsion towards uncertainty, liberal doubt or sensitivity to qualifications in an argument. Prejudices also arise against certain social roles such as academics, care workers, immigrants or some members of officialdom. The attacks on Archbishop Williams, who is himself an academic, were undoubtedly fuelled by these prejudices.

None of this contradicts the fact that many wider structural causes affect the way media present events, thoughts and attitudes, not least those of ownership and advertising. But the professional writing techniques of journalism, which, as I have suggested here, play a significant determining role, are not directly caused by such external factors. As both Van Dijk (1988) and Deuze (2005) have noted, there is some autonomy in the journalistic professional practice reflected across different ownership and regulatory patterns.

The distrust of intellectuals and intellectualism may be peculiar to Britain. However, such a restriction does not detract from the general argument that news media frame an implicit cultural policy - and this may be extended to many similar free-market liberal democracies. Since global journalism has much common lineage, there are assuredly some cross-regional correspondences in practices and wider tacit social effects, especially in Western democracies (in which would be included Australia and New Zealand). Historically, the 'metropolitan' countries like Britain took practices and understandings of media to their dominions. According to Golding, the media in Africa, Latin America and Asia 'do not appear spontaneously at an appropriate moment in social evolution but have been transplanted from metropolitan centres' $(1979$, p. 291). The tendencies towards convergence are further strengthened by the market orientation of journalism and the shared features of funding regimes, in particular a dominating competitive need to survive amid delicately balanced profit margins.
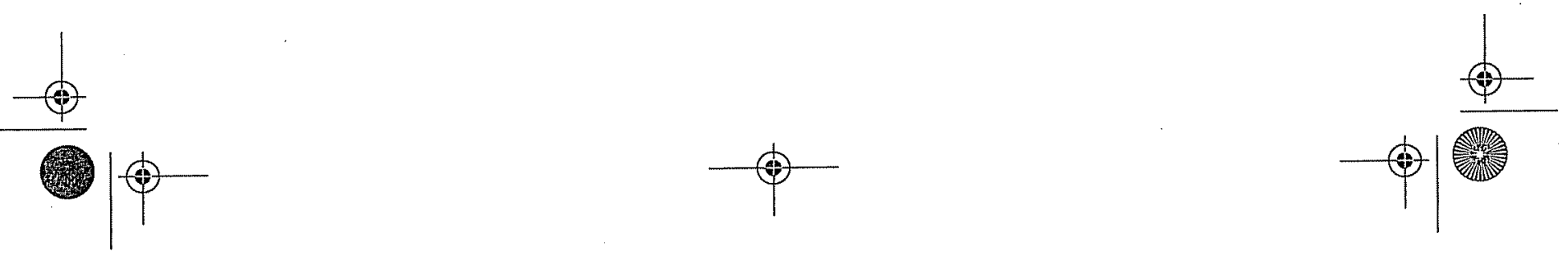
In Europe itself, professional practices and understandings of the role of the journalist show considerable conformity, with many shared perceptions between newspaper journalists (Heinonen and O'Sullivan 2008). Returning to the theme of immigration, Eric Hobsbawm tells us that immigration is now widely perceived as a generalised social "prob-

$5 \quad$ lem' and that the exaggeration and alarm which typify national reactions are way out of proportion to the statistical reality of the events $(2006, \mathrm{pp} .4,39)$. It is reasonable to conclude that such reactions are almost certainly initiated and promoted by shared media assumptions.

Rather at the limit of the scope of this discussion is the linked question of the extent of 10 'media imperialism'. It is clearly possible, though it would require further elaboration, to reconceptualise media 'imperialism' as a form of implicit cultural policy conducted across and between nations and regions. The BBC World Service is undoubtedly regarded by the UK government as a cultural vehicle, on account of the values it is seen to exemplify through its so-called neutral news postures. Its World Service is funded partly by the 15 government as an implicit 'advertisement' or as 'soft power' for Britain, asserting and promoting liberal cultural values. Agence France-Presse, which is supported by the French government, might be seen in much the same way as a vehicle for French influence.

\section{Evidence of influence}

Finally, having discussed some apparently self-contradictory practices of English-speaking journalism, it is time to reflect on how state policy-makers in the UK may be influenced by the uniform media images of hostility towards some cultural issues, or indeed, in the Gramscian sense, how political players may exploit them in their struggle for hegemony. Thus, we can see in the British case how the Blair Government espoused stringent policies against immigrants, for example, in the 'zero acceptance' policy of 2002 that included new measures for speeding up deportation (Cohen 2002, p. xxi). Then, in addition, there is the evidence that the Conservative Party in its bid for hegemony in 2005 played 'the race card' as part of its election campaign (The Guardian 2005, 7 May).

According to Lauren McLaren and Mark Johnson, writing in the 21st Annual British Social Attitudes Survey, the 'traditional acceptance of multicultural practices in Britain seemed to come under sustained direct attack from the Labour government, aided and abetted by the Conservative opposition' $(2004$, p. 191). The survey, published by the National Centre for Social Research, showed that the proportion of the UK population wanting the number of immigrants to be curbed increased from two-thirds in 1995 to three-quarters in 2003 (p. 172). The survey added that Former Home Office Minister David Blunkett made increasingly authoritarian claims about how immigrants should behave in their own homes (p. 191).

The extent of media influence, even on individual policy decisions, is acknowledged by 40 the UK Government ministers. In their report on the power of newspaper columnists, Hobsbawm and Lloyd cited the testimony of both ministers and political aides (2008). Charles Clarke, a former Home Office Minister, admitted that "of course the commentariat are powerful' and an anonymously quoted policy adviser in Prime Minister Blair's office also acknowledged that they 'took a close interest in what commentators [were] saying, but 45 not necessarily more than the news pages' (Hobsbawm and Lloyd 2008, p. 14). Despite the modesty that news commentators expressed about their political influence, Hobsbawm and Lloyd concluded that "whether or not they sincerely believe that they have little or no influence, that belief is false. Commentators [in newspapers] are taken seriously by most of those who constitute the political class' (p. 34). 
The argument of this paper has thus been that the mostly unregulated market-driven media set the framework in which cultural actions are taken, define the references of argument, and create a system for channelling public mentality from behind a facade of selflegitimation that pretends to neutrality. This system is learned within the media. It is taught both in the offices of news workers and increasingly in British universities, where young would-be media beings are broken in to the practices of news. Hegemonic thought patterns, spewed through headlines, sprayed across screens with almost self-mocking certainty, are given eternal sustenance by the populist cultural policies of marketised media. The effect is perhaps worse than that so savagely depicted by Adorno - not just eternal banality and petrified relations (Adomo 1991, p. 86) - but an endless insidious intent to erase the strange.

Notes

1. I am indebted to the websites and journalism research of Masters students at Bournemouth University, UK, for a 'corrective' view of some immigrant experience (see http://journalism. bournemouth.ac.uk/gketels).

2. These insights into the enculturation of the print journalist are based on the author's 15 years as a journalist in national and regional British newspapers and New Zealand. These impressions gained at first hand in a spectrum of the press are supported by two other former print journalists, who are quoted here on a basis of anonymity.

\section{References}

Adorno, T., 1991. The culture industry: selected essays on mass culture. London: Routledge.

Allen, J., 2008. News style guide [online]. BBC Training and Development. Available from: http:// www.bbctraining.com/pdfs/newsstyleguide.pdf [Accessed 16 March 2009].

Archbishop of Canterbury, 2008. Sharia law - what did the archbishop actually say? [online] Available from: http://www.archbishopofcanterbury.org/1581 [Accessed 15 March 2008].

Baines, P., Egan, J., and Jefkins, F., 2003. Public relations: contemporary issue and techniques. Oxford: Butterworth-Heinemann.

Bennett, O., 1995. Cultural policy and management in Europe. Tidskrift. für kultur studier, 1, 108-120.

Bennett, O., 2006. Intellectuals romantics and cultural policy. International journal of cultural policy, 12 (2), 117-133.

Bennett, O., 2009. On religion and cultural policy: notes on the Roman Catholic Church. International journal of cultural policy, 15 (2), 155-170.

Bernstein, J.M., 1991. Introduction. In: T. Adomo, ed. The culture industry. London: Routledge.

Carey, J., 1992. Intellectuals and the masses: pride and prejudice among the literary intelligentsia 1880-1939. London: Faber and Faber.

Chomsky, N., 1988. Manufacturing consent. New York: Pantheon.

Cohen, S., 2002. Folk devils and moral panics. London: Routledge.

Cranmer, 2008. Archbishop of Canterbury: 'Shari'a law in Britain is 'unavoidable' [online]. Available from: http://archbishop-cranmer.blogspot.com/2008/02/archbishop-of-canterbury-sharia-law-in. html [Accessed 9 October 2008].

Curran, J., 2002. Media and power. London: Routledge.

Curran, J. and Seaton, J., 1988. Power without responsibility: the press and broadcasting in Britain. London: Routledge.

Deuze, M., 2005. What is journalism? Professional identity and ideology of journalists reconsidered. Joumalism, 6, 442-464.

Furedi, F., 2004. Where have all the intellectuals gone: confronting 21 st century philistinism. New York: Continum.

Galtung, J. and Ruge, M., 1965. Structuring and selecting news. In: S. Cohen and J. Young, eds. The manufacture of news. London: Constable, 62-72.

Golding, P., 1979. Media professionalism in the third world; the transfer of an ideology. In: J. Curran, M. Gurevitch, and J Woollacott, eds. Mass communication and society. Beverly Hills: Sage, 281-308.
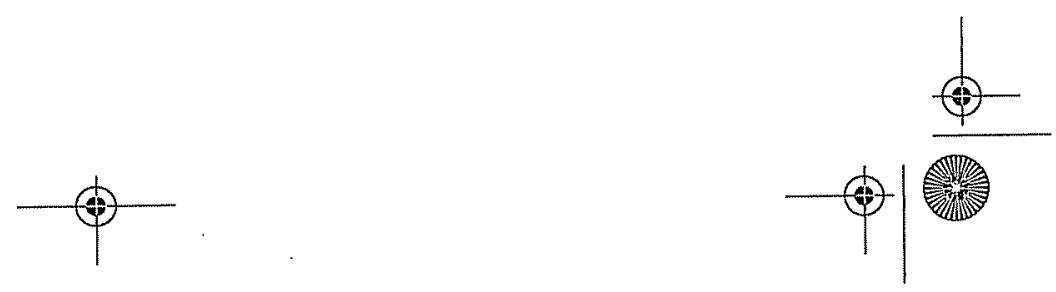
The Guardian, 2005. Now for the hard part (leader) [online]. Available from: http:/www.guardian. co.uk/politics/2005/may/07/liberaldemocrats.election2005 [Accessed 7 May 2007].

Hall, S., 1978. Policing the crisis: mugging, the state and law and order. London: McMillan.

Harris, G. and Spark, D., 1995. Practical newspaper reporting. London: Routledge.

5 Heinonen, A. and O'Sullivan, J., 2008. Old values, new media. Journalism practice, 2 (

Hobsbawm, J. and Lloyd, J., 2008. The power of the commentariat [online]. The Editorial Intelligence Ltd in association with Reuters News Agency. Available from: http://reutersinstitute. politics.ox.ac.uk/uploads/media/Power_of_the_Commentariat.pdf [Accessed 28 May 2008].

House of Lords Select Committee on Economic Affairs, 2008. The economic impact of immigration [online]. HM Stationery Office. Available from: http://www.publications.parliament.uk/pa/ld/

10 Ideconaf.htm [Accessed 4 March 2008].
International Union for Muslim Scholars, 2008. Positive attitude of the archbishop of Canterbury: press statement [online]. Available from: http://www.iumsonline.net/english/articles/2008/02/ 01.shtml [Accessed 10 October 2008].

Kamen, H., 1967. The rise of toleration. London: Weidenfeld and Nicholson.

Katz, J., 2001. Net, our most serious news medium (slashdot.org, cited in S. Allan 2002. Reweaving the Internet). In: B. Zelizer and S. Allan, eds. Journalism after September 11. London: Routledge.

Leavis, F., 1930. Mass civilisation and minority culture. Cambridge, MA: The Minority Press.

McGuigan, J., 1996. Culture and the public sphere. London: Routledge.

McLaren, L. and Johnson, M., 2004. Understanding the rising tide of anti-immigrant sentiment. In: A. Park et al., eds. The 21 st Annual Report on British Social Attitudes Survey. London: Sage.

McNair, B., 2006. Cultural chaos: journalism news and power in a globalised world. London: Routledge.

Media Workers Against the War, 2008. At a glance: Sharia law in Britain [online]. Available from: http://www.mwaw.net/2008/02/12/sharia/ [Accesșed 10 October 2008].

Mill, J.S., 1859. Utilitarianism. London/Glasgow: Fontana.

Nye, J., 2005. Soft power: the means to success in world politics. New York: PublicAffairs.

Orr, D., 2008. Don't be fooled: the archbishop wants to beat extremists at their own game. The Independent [online]. Available from: http://www.independent.co.uk/opinion/commentators/ deborah-orr/deborah-orr-dont-be-fooled-the-archbishop-wants-to-beat-extremists-at-their-owngame-780195.html [Accessed 20 March 2008].

Orwell, G. 1970. Propaganda and demotic speech. In: The collected essays, journalism and letters of George Orwell. Vol. 3 (As I please, 1943-1945). Harmondsworth: Penguin (Original work published 1944).

30 Said, E., 1994. Representations of the intellectual. The 1993 Reith lectures. London: Vintage.

Sellers, L., 1985. The simple subs book. Oxford: Pergamon.

Simon, R., 1982. Gransci's political thought: an introduction. London: Lawrence and Wishart.

Sparks, C., 2003. Inside the media. International socialism journal, 98 (1) [online]. Available from: http://pubs.socialistreviewindex.org.uk/isj98/sparks.htm [Accessed 4 March 2008].

Sunday Times, 2007, 4 November. [online]. Available from: http://www.timesonline.co.ak/tol/ comment/columnists/guest_contributors/article2800980.ece [Accessed 12 April 2008].

The Sun, 2008, 8 February. [online]. Available from: http://www.thesun.co.uk/sol/homepage/news/ article778163.ece [Accessed 10 April 2008].

Tuchman, G., 1978. Making news: a study in the construction of reality. New York: Free Press.

Tunstall, J., 1971. Journalists at work: specialist correspondents, their news organizations, news sources, and competitor - colleagues. London: Constable.

$40 \quad$ Van Dijk, T., 1988. News analysis: case studies of international and national news in the press. Mahwah, NJ: Lawrence Erlbaum Associates.

Williams, R., 1958. Culture and society 1780-1950. Harmondsworth: Penguin.

Williams, R., 2008. What did the archbishop actually say? [online]. Available from: http:// www.archbishopofcanterbury.org/1581 [Accessed 10 March 2008].

Young, A., ed., 1961. The letters of George Gissing to Edward Bertz. London: Constable, 151-152. 